\title{
The soil in the lines of my mehndi: Toward a decolonial ritual choreographic methodology
}

\author{
Alesha Mehta $\&$ Sarah Foster-Sproull \\ University of Auckland, New Zealand
}

\begin{abstract}
This article explores instigating ritual movement practices as a decolonial approach to practice led research within a Western liberal arts context. By connecting ritual with movement through a decolonial lens, a choreographic methodology was explored to enable belonging, cultural identity and empowerment to evolve within postgraduate practice led research. Ritual movement processes may involve trial and error as well as deep experimentation to unveil and unpack decolonial experience. Building from student-centred personal reflections, this article proposes that ritual movement practice may allow for cultural representation, belonging and decoloniality to occur within a neoliberal educational context. To explore this realm a central query evolved, how might ritual movement practices instigate a decolonial student experience within postgraduate practice led research?
\end{abstract}

Keywords: ritual; decoloniality; creative practice; postgraduate research; choreography

Received: February, 2021; Accepted: July, 2021; Published: November, 2021

\section{Opening the space: Alesha's reflexive beginning}

I pick up my red lighter in my right hand and use my left hand to protect each incense stick as I ignite the end before gently blowing out the flame, ensuring the smoke is releasing. I begin walking towards the marigold circle, pressing my feet into the cold damp soil with each step. I slowly raise my head and I begin to look at each person in the eyes, with my hands over my heart. I sit down and place my hands in the soil, allowing my weight to sink them deeper into the land. I bring my hands to a prayer at my chest and then I reach my hands to the sky. I open my eyes and look through my hands, I see the soil in the lines of my mehndi, henna, filling each indent and line with damp earth. As I gaze over to the audience in the space with me, and my cultural adornments surrounding us, I place my fingers at the edge of my mouth, close my eyes, lean back and open it to the sky. (Mehta, 2020, p. 18)

^Correspondence: Alesha Matha, e-mail: wallabh.alesha@gmail.com

(C) 2021 A. Mehta \& S. Foster-Sproull. This is an Open Access article distributed under the terms of the Creative Commons Attribution 4.0 International License (https://creativecommons.org/licenses/BY/4.0/), allowing third parties to copy and redistribute the material in any medium or format and to remix, transform, and build upon the material for any purpose, even commercially, provided the original work is properly cited and states its license. 
Alesha's narrative shares an experience of a solo postgraduate research performance called Shakti Puja and part of the ritual process that was intertwined to construct the choreography. As an Indian woman born and raised in Aotearoa, New Zealand, Alesha's personal feelings of belonging have been complex and to navigate feelings of belonging, developing a ritual choreographic methodology enabled her to ground her identity and practice within an institutional context. To capture some of the energy and complexity of this proposition, within this article we, as a student and supervisor team, explore how ritual within practice led research focusing on an Indian cultural lens in Aotearoa New Zealand may instigate a decolonial student experience. The embodied movement experiences and rituals instigated by Alesha Mehta provide the lens through which decoloniality is considered within this article and to ask the question: How might ritual as a movement methodology instigate decolonial student experience within practice led research? Within this article we incorporate Alesha's reflections as first person narratives and activate a subsequent third person discussion of the findings to honour the shared discoveries of both student and supervisor. We offer this approach as a decolonial critical practice that names all contributing parties.

\section{Grounding the practice: A qualitative, post-positivist, practice-led approach}

This research adopts a qualitative methodological approach (Denzin, 2008) to seek meaning through words as opposed to numbers and focuses on rich contextual information informing the creative practice (Phillippi \& Lauderdale, 2018; Weiss, 1995). A post-positivist approach allowed the unpacking of complex experiences of identity and their multiple truths (Ryan, 2006), as well as created a lens through which to view the cultural context of the research alongside the multimodality of the practice (Green \& Stinson, 1999). From a creative practice perspective, the ritual methodology activated in this research involved sensory, aesthetic and embodied approaches to dance making that include incense, meditation, adornment, channelling energy, sound, mantra and movement.

A practice-led approach was utilised to deeply explore sensory, aesthetic and 'felt' research propositions through an embodied lens (Roche, 2015) and allow for the active navigation of experiences of belonging and decolonisation within solo choreographic practice. Dance scholar Efrosini Protopapa (2011) discusses practice led research as a relationship between practice and theory that enables creative connections, collisions and complex theoretical intersections to occur. Practice led research strives to "lead research from practice" (Haseman, 2006, p. 100), also described as learning in and through practice and reflection (Mcniff, 2013). Applying a practice led research approach to this choreographic practice enabled the process of embodying ritual to inform personal understandings of cultural heritage within an institutional context. 


\section{A. Mehta \& S. Foster-Sproull}

\section{Channelling of knowledge: Decoloniality}

In this article we utilise a decolonial lens to explore the leading question: How might ritual as a movement methodology instigate a decolonial student experience within practice led research? We propose that this approach allows an exploration of identity through cultural representation, movement, performance design, ritual and location. Donna Chambers \& Christine Buzinde (2015) acknowledge decolonial theory as a tool to explore other ways of knowing and being that does not "privilege Western epistemologies" (p. 5). Tracey Banivanua Mar (2016) notes the process of decolonisation begins from the mind through to voice, to language and then moves outwards toward practice, cultural revival and custom. Within this research exploration of cultural heritage through adornment of the body and space, through movement vocabulary and ritual processes allowed the dissipation of performance perfectionism (Stoeber, 2012) that may be found in Western concert dance (Lakes, 2005).

The purpose of decolonisation in this research is not to disengage with the West (Chakrabarty, 2005), but to unveil how cultures may become altered through Western understandings (Grande, 2008). Syed Hussein Alatas (2000) discusses colonisation of the mind as "domination of one people by another in their world of thinking" (p. 24). Through this lens it could be possible that a Western education system perpetuates the dominant cultures interests as "universal and mutual" (Plumwood, 2002, p. 8). This perspective led us to consider how creative practice could become decolonised, so that Alesha's Indian heritage and performance modes could live, grow and thrive in the complex terrain of Western research methods (Oldfield \& Forrester, 2018).

A decolonial process may seek to create new methods of analysis that best serve cultural and Indigenous experience and knowledge (Oldfield \& Forrester, 2018). Unsettled by Edward Said's (1978) identification that there is a Western perception of superiority "in comparison with all non-European peoples and cultures" (p. 13), we note that Eurocentric privileging may still be evident within some choreographic practice in Aotearoa over forty years later.

Within this research the reclamation and personal revitalisation of Alesha's Indian cultural heritage is a crucial process of decolonisation (Battiste \& Henderson, 2000), where the identity building practice relies on "uncolonising the mind, speech, knowledge and space" (Mar, 2016, p. 225). Translating Indian knowledge and concepts in an institutional context (Raina, 2012) and the hybrid experience that may occur through the in-betweenness of two worlds (Bhabha, 1994) is complex. Indian dancer, choreographer and scholar Priya Srinivasan (2019), discusses the decolonising experience that may occur when utilising dance, song or visual art to "channel the past to forge present and future connections" (p. 216). An exploration of these connections of past, present and future, or connections of East and West (Organ, 1986) may become complex hybrid cultures (Bhabha, 1994), within practice led research. As such, the process of decolonising practice-led research may allow for an oscillation 
of epistemological methods that allows for an exploration of Eastern and Western lineage of identity, body and space (Srinivasan, 2019).

\section{Ritual practice}

The ritual practices utilised within this choreographic research are incense, meditation, adornment, channelling energy, sound, mantra and movement. Ritual practices aligned with Alesha's experiences of belonging and identity because these practices were prominent in her upbringing and are currently active within her current environment. Rituals may mean different things at different points in a person's life, within societies and between people of the same culture (Doty, 2000). Writer Jamake Highwater (1978) discusses ritual as an act of transforming both the external and the internal experience, which may allow for meaning making to occur before, during and after the ritual is complete (Duncan, 1995; Manning, 2000). Where the ritual is performed communicates an idea about the act itself and it is possible that certain environments may treat the term ritual as a "lower term in a hierarchy" (Duncan, 1995, p. 5). However, within this research we propose that ritual may be an essential part of 'channelling' performance within a creative practice context.

Kathleen Manning's (2000) research explores rituals, ceremonies and cultural meaning in higher education. Because there is limited literature on ritual choreographic practice as a method for connecting to cultural heritage, it became necessary for Alesha's solo performance to provide explorations from within an institutional context. Manning's (2000) research identifies several rituals that occur within the context of higher education and in response, through discussion, unpacking, critical thinking and multimodal research explorations, Alesha chose to draw seven key rituals into her choreographic process: adornment, incense, meditation, channelling energy, sound, mantra and movement. Alesha chose these seven elements within her ritual method as they allowed her to identify her connection through sensorial activations of home, identity and belonging. Furthermore, these seven elements allowed Alesha to curate and develop her ritual practice and embed it within her creative practice as an alternative way to 'channel' performance within choreographic research.

\section{Ritual practice: Incense}

Within Alesha's postgraduate performance Shakti Puja incense was used as a symbol that connects with Alesha's Indian heritage and as a method to elevate selfawareness through scent (Pennacchio et al., 2010). Incense is discussed by scholars as being used in various transition marking ceremonies such as: weddings, baptism and funerals and for its ability to transform space (David, 2012; Hutchings, 2010; Mckenna \& Hughes, 2007). Additionally, incense was and is still used in sacrificial or holy places, temples or ornamented arenas (Michaels, 2016), it may signify elements of a higher realm allowing practitioners access to an elevated energy that may have 


\section{A. Mehta ES S. Foster-Sproull}

been otherwise closed (Ergin, 2014; Mckenna \& Hughes, 2007). Furthermore, in Alesha's practice, incense was used to redefine and reframe the suburban location (David, 2012) of the institution. Transforming the space through smell may allow access to re-enter a past world, past state of mind and recapture the energy of a particular place (Drobnick, 2002). Jyoti Kapur (2019) suggests "smell and touch are intimate senses, they not only create a sense of position (geography) but also an emotional bond between the person and the environment" (p. 252) Additionally, " $[t]$ he power of smell [may be] a key indicator of place, offering a kind of olfactory anchor for being-in-the-world" (p. 37). Incense within this research allowed access to sensorial feelings of place and home.

\section{Ritual practice: Meditation}

Within this student led creative practice meditation was utilised as a method to allow access to identity by enhancing well-being and establishing a higher awareness of self (Pinxit, 2019). Meditation practice is diverse, and originating from the East it has been practiced by Buddhists and Hindus for thousands of years (Park \& Pyszczynski, 2017; Sun, 2019). Gupta, Russell and Lo (2007) suggest that "meditation is where the mind is in an absolute state of non-doing" (p. 52). However, Timothy Morton (2010) notes that meditation does not refer to emptying the mind or supressing the intellect but involves experiencing an inner interconnectedness. Meditation may enable creative practitioners to consider how they feel at any given point in time (Bødker, 2017), draw their attention to the present moment (Curran, 2013), access intuitive knowledge, and connect with 'gut feelings' or knowledge that is unexplainable (Wiebe, 2015). Mads Bødker (2017) states,

... a meditative approach compels the person meditating to attempt a situated and sensuous form of knowing; to try to observe and recall how her/his senses are at work, assess what senses are active or dominant in a situation and what feelings emerge in the situation at hand (p. 278)

Bødker (2017) proposes that meditation can allow a person to sit with and in their feelings as opposed to dissipating them, guiding them to be fully themselves (Salazar, 2013). Alesha noted that meditation allowed an experience of 'grounding' the practice prior to the experience of 'becoming' with and in her cultural identity. Meditation occurred at the beginning and at the end of the practice, and a focus on the sensations, feelings, perceptions and emotions that arise with non-judgemental acceptance enabled Alesha to stay present (Kabat-Zinn, 2003; Park \& Pyszczynski, 2017). We propose that enabling a student researcher time to connect and 'be' through meditation may allow them to clearly guide how the research needs to unfold. Certainly, meditation enabled Alesha to consider her presence and attention within the performance and guide how adornment may connect her with her cultural heritage. 


\section{Ritual practice: Adornment}

Within the choreographic ritual, adornment was explored as a method of decorating the space and body within the performance (Francis, 1984), and as a process of representing cultural heritage. Llewellyn Negrin (2006) discusses $19^{\text {th }}$ century adornment and how,

it was believed [women], collected artefacts in accordance with the whims of fashion, viewing them simply as items of decoration without any deeper intellectual purpose, while the collection of art by men was informed by a carefully thought through philosophy and purpose (p. 223)

In response to the above proposition, the process of adornment within this research seeks to be explored as a political act and not as a "whim" (p. 223), but an essential connection to cultural heritage and experiences of belonging, becoming and being. Incense, marigold flowers, serpent deities and saree material were used to enrich the performance space with meaning about identity, as well as shift the environment to be culturally representative (Crossley, 2003; Negrin, 2006). Debra Roth (2006) proposes that "the practice and effects of adornment alter the substance and shape of encounters with a world within, as well as beyond, the boundaries of the self" (p. 185). The process and practice of decolonising the environment through adornment unveiled feelings of connection to cultural heritage through a connection to meaningful material objects.

Within the process of adorning the environment, there was a consideration of the performative capacities of the materials and objects (Monforte, 2018), and how the materials in the space inform how the performer and audience may approach the environment (Fowler-Smith, 2018). Debra Roth (2006) proposes the practice of adorning the self may "initiate a weightier sense of both having and being" (p. 185). Adorning the environment may allow a person to feel as though they have their culture surrounding them, as seen in Aotearoa, New Zealand/Indian artist Gemishka Chetty's work So Where Do You Really Come From? (Chetty, 2018), which utilised fabric drapes and cultural objects to create a space representative of her cultural identity. Alesha viewed the practice of adorning the performance space with saris and Durga effigies to be decolonial as it allowed Alesha to feel connected to her culture through material objects and to bring meaningful artefacts from her home onto the campus. Adornment signified a process of channelling energy from her home to reshape the campus environment.

\section{Ritual practice: Channelling energy}

Channelling within this creative practice is discussed as a process to explore the spiritual and emotional nature of 'something more' (Manning, 2000, p. 2) from a secular perspective. To access this state Alesha's practice centred on initiating a ritual movement that embodied the energy of Durga the Hindu Goddess (Amazzone, 2010). 


\section{A. Mehta \& S. Foster-Sproull}

The secular perspective of this research seeks to explore ritual to become personal cultural heritage, therefore, Alesha explored Durga through invoking her power and moving in response. This process of channelling involved Alesha's personal exploration and connection to Shakti (feminine energy) through Durga and recognises that Goddesses may be given different meanings and understandings by different women (Rountree, 2004). Although ritual is often associated with religious practices, magic or symbolic sacrifices (Duncan, 1995), channelling within ritual in this context seeks to access altered consciousness and performative transformation (Duncan, 1995). This approach connects with the performance practice of Jahra Wasasala (Wasasala, 2020) a choreographer, poet and movement performer of Fijian descent based in Aotearoa New Zealand. Alesha was introduced to Jahra through Orchids directed by choreographer Sarah Foster-Sproull (Young, 2017), and reflected that Jahra's performance was informed by "something more" (Manning, 2000, p. 2) that instigates,

... a powerful totemic grotesquerie, contorting her face and body to resemble the Hindu goddess Kali, destroyer of evil forces, appearing as if in a state of possession (Young, 2017, p. 1)

Jahra's performance in 2017 connected to Kali in such a clear way that her performance channelling generated a sense of permission for Alesha to delve deeper into her cultural heritage within her exploration of Durga. Drawing connections to other practitioners work informed the evolution of Shakti Puja and posed some additional questions about cultural ownership and responsibility that sit outside the scope of this research project.

\section{Ritual practice: Sound}

Channelling was continued within the sonic component of the research and playing a chant dedicated to Durga was a deliberate act to enable a deeper connection between Alesha, Durga and the movement practice being evolved. Sound in Hindu India has powerful significance stemming from belief in the cosmic power of language and its ability to transform (David, 2012). Additionally, music can link to a person's homeland (Slobin, 1994), which for diasporic communities, may enable a sense of 'place' to be established (Smith, 1994). Sound within this research is accessed through mantra and as a tool to affect physical movement (Atkinson, 2007). Sound also plays a part in the purification of space and may inform a person's relationship to the environment (David, 2012).

Mantra became an increasingly important method of honouring the deities (Babb, 1970) within Alesha's work. Dance practitioner and artist Sara Parker (2015) discusses mantra within her practice in choreography and performance as enabling "dancers to consciously set thoughts into the piece" (p. 28). Connecting to mantra in choreography and performance, Duncan (1995) proposes that ritual does not need to be a "formal spectacle [but rather] something an individual enacts alone by following 
a prescribed route, by repeating a prayer, by recalling a narrative" (p. 12). The mantras utilised in this research connect to Durga, and the composition played in the performance was carefully planned (Liu, 2018). By incorporating mantra, there was an aim to "infuse the space with a desired intention for the creative work that was to occur" (Parker, 2015, p. 28). Within this research mantra is used as a ritual tool to invoke "something more" (Manning, 2000), and to begin movement practice with a clear intention.

\section{Movement}

Movement practice within this research mindfully oscillated between improvisational, structured, hybrid and scored choreography to further explore the research query: How might ritual as a movement methodology instigate a decolonial student experience within practice led research? It was through these shifting approaches that Alesha felt able to stay connected to the needs of being and becoming her Indian cultural identity within a postgraduate research context. As this research began, feelings of striving to suit the expectations of Western concert dance (Lakes, 2005) and notions of virtuosity within this environment were negotiated and to counter this, the research utilised improvisation as an authentic expression of practice (Evola \& Skubisz, 2019).

Through improvisation, constructing movement scores and rigorous discussion, Alesha considered how she might establish a ritual movement methodology that allowed her performative freedom and cultural authenticity. This creative practice engaged with structured improvisation to generate movement in response to culturally specific stimuli (Biasutti, 2013) as well as enabled Alesha to listen carefully to her "bodies inclinations" (Cohen, 2010, p. 105). Within this practice, there was a desire to explore cultural heritage without judgment and without the desire for performance perfectionism (Stoeber, 2012). Improvisation may enable a balance between internal and external awareness (Schwartz, 2000), as it may allow access to connect to emotional, spiritual and physical insights (Williamson, 2009). Additionally, Peggy Schwartz (2000) suggests many dancers know the experience of "being danced, the moments of embodiment when body, mind, spirit and music all become one” (p. 44). Through adopting a range of ritual, improvisational and structured choreographic approaches the research was led instinctively toward what it 'needed to be' rather than what may have previously occurred in Alesha's previous creative practice works.

\section{Decolonial experiences of being: Examination, space and embodiment}

Situating Shakti Puja on the campus grounds was a political act (Franko, 2006) that had to negotiate institutional rules and expectations (Ramirez \& Christensen, 2013; Reid, 2007). The complexities of examination processes, time, studio space availabilities and a desire to forge a path for Indian creative practice to evolve was challenging. To negotiate the complex realm of decolonial creative practice and institutional 


\section{A. Mehta E্ S. Foster-Sproull}

examination requirements, decisions were made about the parameters of assessment. Through critical dialogue in supervision with Sarah, Alesha chose to have the live performance outcome unexamined to allow the decolonial nature of the research to unfold in three ways. Firstly, to ensure power was explicitly given to the performer as a woman of colour and choreographer to make decisions about how the creative work is assessed. Secondly, engaging in ritual methods enabled Alesha to connect with her cultural heritage on campus at the site specific performance location. Additionally, the ritual practices enabled her to connect with her audience in a personal way, un-impinged by the examination process which may be concerned with creating a definition, grade, or quantification (Scarlett, 2018) of embodied experience of cultural heritage. Thirdly, the decision for the creative work not to be examined allowed Alesha to challenge Western notions of technical "virtuosity" (Lakes, 2005) and judgement as a decolonial act. The practice of Shakti Puja pushed notions of definitive structure, repeatability and performance perfectionism (Stoeber, 2012) sometimes found within Western concert dance (Lakes, 2005). Alesha explored this pushing of definitive structure and performance perfectionism by incorporating slowness, gaze with the audience, meditation and utilising structured improvisation to drive the performance. Therefore, we propose that in some instances choosing to not have the performance examined may enable an artist to empower their creative decision making and define their performance experience on their own terms.

The research seeks to decolonise thinking and bodily exploration of knowledge (Mar, 2016), in order to forge a path for Indian creative practice to evolve. However, within the creative practice process of Shakti Puja Alesha navigated feelings of emotional distress (Benoot $\&$ Bilsen, 2015), because actively decolonising creative practice for this research meant decolonising the mind (Mar, 2016), in order to prioritise Indian cultural knowledge as a choreographic framework. Within the first week of research it became apparent that lighting incense in the dance studio would not be a possibility due to smoke alarms in the building, therefore the ritual practice was influenced by the spatial setting (Hampton, 2017) and the institutional rules surrounding the practice (Ramirez \& Christensen, 2013; Reid, 2007). Initially, experiencing enacting, living and presenting cultural identity within the dance studio was important to Alesha as a means of situating her identity in a space predominantly used for Western dance forms. After a work-in-process showing with supervisor Sarah, Alesha reflected "I feel I am taking too long to chant my mantras". The rules of the institution (North, 1990) impacted the performance experience and ability to channel performance energy in an authentic way. During the showing an awareness of time and the experience for the person watching became prominent and a feeling of 'performing' cultural identity rather than 'being' cultural identity (Marinetti, 2018) occurred. The navigation of institutional rules (Ramirez \& Christensen, 2013; Reid, 2007) led the practice to be shifted outside on campus grounds under a Norfolk pine tree to continue to allow the practice to unfold in a way that suited the needs of the performer. 
Shifting the work outside allowed the ritual process to be fulfilled without it bending to the institutional rules surrounding the interior studio practice (Ramirez \& Christensen, 2013), and an additional layer of adorning the natural space with representations of Indian culture through fabric and objects. To gather additional cultural support Alesha instigated a conversation with Ngāti Hine artist and University of Auckland Dance Studies Lecturer Dr. Tia Reihana-Morunga about notions of adorning sacred land with cultural objects. Alesha began researching into the Waipapa Marae at the University of Auckland and began to understand that "a Kaupapa Māori sense of place connotes a feeling of belonging to that place as opposed to that place belonging to you" (Hoskins, 2008, p. 29). For this research, a site specific location outdoors acted as a place where an authentic exploration could occur (Hiroti \& Martin, 2021; Hoskins, 2008) and where an active connection to the land could occur through movement (Brown \& Reihana-Morunga, 2020). Practices of adorning the environment channelled an experience of belonging to the land, rather than recognising ritual practice as using the land.

The performance location was under a giant Norfolk Island pine tree near Old Government House on campus. There was native Kawakawa around the base of the tree with a clearing in the centre where the performance occurred. This location was selected as it had indications of the suburban location (David, 2012), through glimpses of Waterloo Quadrant road and the Auckland High Court from the front. Curating an environment using material that is used to adorn the body, shifted the space to become 'clothing' to shield and protect Alesha (Sanders, 2002, as cited in Gorman-Murray, 2008), and provide additional layers to articulating identity. The performance space incorporated a circle of marigolds in the centre of the land, serpent deities, incense and sarees. In Alesha's journal she reflected on her association with marigold flowers by saying "I feel like marigold flowers represent me in a way, their two-tone colour reflects my identity of being in two worlds". Marigold flowers are also utilised in Hindu home altars as an offering to the Goddesses and Gods (Mazumdar \& Mazumdar, 2009), and incorporating marigold flowers allowed Alesha to continue the practice of channelling power and energy from Durga. Alesha placed serpent deities that she kept in a shrine at home which allowed her to refract the home landscape to the outdoor environment (Tolia-Kelly, 2004, as cited in Gorman-Murray, 2008). The process of adorning the performance space became a shaping and representing of cultural identity as well as a process of place making (Blunt \& Dowling, 2006). As fabric and objects were placed around the tree and bark at The University of Auckland, Alesha noted experiencing a feeling of familiarity and connection with the site specific location.

Representation through material objects was vital to the experience of being and becoming (Marinetti, 2018) Indian cultural identity. Due to the solo nature of this practice Alesha sought to incorporate objects that represented relationships and events in her life (Rose, 2004), allowing a feeling of connection to cultural heritage to occur. For example, draping the trees in sarees owned by her mother and 


\section{A. Mehta ES S. Foster-Sproull}

grandmother as well as incorporating objects (marigolds, incense, deities) into the performance space, allowed the space to morph and display difference to reshape the environment (Jacobs \& Malpas, 2013). Additionally, this research connects to Indian/ Aotearoa, New Zealand artist Gemishka Chetty and her work in collaboration with Thai Chinese artist Aiwa Pooamorn (Teng, 2013) which critiques Asian stereotypes. By exploring decolonial practice in their art, Gemishka and Aiwa (Teng, 2013) access cultural adornment as a means of political activation through an intersectional feminist lens. This raised questions about the renderings of representation and identity that appeared in Gemishka Chetty's and Aiwa Pooamorn's work, and consequently resonated with Shakti Puja.

As the creative practice shifted outside, an additional layer of entering and exiting the performance space was explored (Manning, 2000). During the performance of Shakti Puja, Alesha guided audience to the site specific location and interacted informally with them during the transition. This was an active decolonial decision to push against traditions of proscenium arch performance where audience may sit in ordered rows, in the dark, surveilling the performers in action. This approach allowed Alesha to feel a sense of ownership over her creative identity through how she engaged with the audience and set the performance up prior to the movement moment. Furthermore, this research contends that the whole performance event including before, during and after the 'movement component' is part of the choreographic design.

The performance began by lighting ten rose incense sticks placed in a circle defining the performance arena. This ritual was designed to give a scent that shifts the environment and initiates a connection between scent and place (David, 2012; Drobnick, 2002). Rose was specifically selected as a fragrance that was meaningful and connected with the ritual practice utilised at Alesha's home. Selecting an incense that was meaningful allowed an emotional bond between performer and the environment to occur (Kapur, 2019). Within the ritual of entering the space, audience members were guided to form a circular arc around the incense. This shape seeks to deconstruct Western performance contexts (Lakes, 2005) by allowing the audience to be in close proximity to the performer and make decisions about where and how they stand. Inspired by Marina Abramović's The Artist is Present (Charles, 2010), and notions of the feminist gaze (Meduri, 1992) Alesha was compelled to look into the eyes of each audience member. This visual connection was a practice of gratitude to feel the generosity, love and support of the people in the space (Chen et al., 2012). Within the performance, every person was acknowledged and invited to witness with Alesha the process of 'becoming' cultural identity.

As Alesha exited the space, she collected the incense to carry to the dance studios and walked backwards out of the performance space. Walking backwards was a decision made to keep the channel between performer, audience and the site open, and to keep some visible material aspects representative of Alesha's cultural identity (Jacobs \& Malpas, 2013). The incense was carried in the right hand as the right hand in Hinduism may be viewed as the hand of power (Babb, 1981). Following this, the 
incense was placed in the soil outside of the studio to represent Alesha's desire to decolonise the dance studio space. This allowed all attendees to continue to smell the fragrance as they began to talk with their friends and whānau, family, after the performance.

\section{Closing the space: Concluding reflections}

This practice led research has been driven by the key question: How might ritual as a methodology instigate a decolonial student experience within postgraduate practice led research? Incorporating Indian cultural heritage into a practice led performance in an institutional context reflected the hybridity of identity and allowed Alesha to resonate with being neither one nor the other (Bhabha, 1994), but a complex amalgamation of two worlds. As such, in this research we recognise that the external environment plays a significant role in the process of 'becoming' cultural identity. Through adornment and performing outside, a performer may explore cultural identity without some institutional rules impacting their ritual movement practice (Ramirez \& Christensen, 2013). We propose that ritual practice may then allow a postgraduate creative practice student to incorporate their cultural heritage through redefining suburban locations using scent (Drobnick, 2002); meditation to enable a state of calm and higher awareness of identity (Pinxit, 2019); placing significant objects in the space representative of personal cultural identity (Crossley, 2003); channelling as a transformative process of invoking 'something more' (Insoll, 2004; Manning, 2000; Duncan, 1995); mantra as infusing the space with a desired intention (Parker, 2015); sound as linking to a sense of place and homeland (Slobin, 1994; Smith, 1994), to encourage students to step into their performance power and feel represented as diverse and distinct artists.

Though this research sought to explore ritual as a methodology within movement practice, the post-positivist lens also recognises there is no singular truth (Ryan, 2006). Due to the intimate nature of exploring cultural identity, we recognise that this research is true to one person's experience of ritual practice and may shift between individuals. Therefore, ritual as movement methodology requires additional research to further understand the complexities of cultural identity and decolonisation within the institution. We propose that minority communities and creative practice research may benefit from enacting a decolonial ritual space, because this research allowed postgraduate creative practice student Alesha to explore new realms and venture to new understandings within herself. However, we recognise there is more to be explored within ritual practices, cultural identity and decoloniality in creative practices. As Alesha's auto-narrative beginning reflected "[...] I open my eyes and look through my hands, I see the soil in the lines of my mehndi, henna filling each indent and line with damp earth" (Mehta, 2020, p.18), we recognise the need to return back to the soil in order to nurture further reflections within the field of decolonial practice led research in Aotearoa, New Zealand and internationally. 


\section{A. Mehta \& S. Foster-Sproull}

\section{Author biographies}

Alesha Mehta is a current PhD student at the University of Auckland with a focus on decolonial choreographic practice methods.

\section{Sarah Foster-Sproull is a choreographer and Senior Lecturer in Dance Studies at the University of Auckland. Sarah holds a Masters in Dance Studies with a research focus on dancers experiences of dance-making and choreographic leadership.}

\section{References}

Alatas, F. S. (2003). Academic dependency and the global division of labour in the Social Sciences. Current Sociology, 51(6), 599-613.

Amazzone, L. (2010). Goddess Durga and sacred female power. Hamilton Books.

Atkinson, R. (2007). Ecology of sound: The sonic order of urban space. Urban Studies, 44(10), $1905-1917$.

Babb, A. L. (1970). The food of the gods in Chhattisgarh: Some structural features of Hindu ritual. Southwestern fournal of Anthropology, 26(3), 287-304.

Babb, A. L. (1981). Glancing: Visual interaction in Hinduism. Fournal of Anthropological Research, 37(4), 387-401.

Battiste, M., \& Henderson, Y. (Sa'ke'j) J. (2000). Protecting Indigenous knowledge and heritage: A global challenge. Purich Publishing.

Benoot, C., \& Bilsen, J. (2015). An auto-ethnographic study of the disembodied experience of a novice researcher doing qualitative cancer research. Qualitative Health Research, 26(4), 482-489.

Bhabha, K. H. (1994). The location of culture. Routledge.

Biasutti, M. (2013). Improvisation in dance education: Teacher views. Research in Dance Education, 14(2), $120-140$

Blunt, A., \& Dowling, R. (2006). Home. Routledge.

Brown, C., \& Reihana-Morunga, T. (2020). Hau. Performance Research, 25(2), 69-78.

Bødker, M. (2017). "What else is there ...?”: Reporting meditations in experiential computing. European fournal of Information Systems, 26(3), 274-286.

Chakrabarty, D. (2005). Legacies of Bandung: Decolonisation and the politics of culture. Economic and Political Weekly, 40(46), 4812-4812.

Chambers, D., \& Buzinde, C. (2015). Tourism and decolonisation: Locating research and self. Annals of Tourism Research, 51, 1-16.

Charles, A. (2010). Marina Abramovic: The artist is present. Artforum International; New York, 48(5), 83.

Chen, H. L., Chen, M., \& Tsai, Y. (2012). Does gratitude always work? Ambivalence over emotional expression inhibits the beneficial effect of gratitude on well-being. International fournal of Psychology, 47(5), 381-392.

Chetty, G. (2018). Gemishka Chetty. https://gemishkachetty.wordpress.com/photography/

Cohen, S. (2010). Sightless touch and touching witnessing: Interplays of authentic movement and contact improvisation. Fournal of Dance and Somatic Practices, 2(1), 103-112.

Crossley, L. (2003). Building emotions in design. The Design fournal, 6(3), 35-45.

Curran, J. (2013). Transcendental meditation: Sustainability studies and Dickinson's breath. The Emily Dickinson fournal, 22(2), 86-135.

David, R. A. (2012). Sacralizing the city: Sound, space and performance in Hindu ritual practices in London. Culture and Religion, 13(4), 449-467.

Denzin, K. N., \& Lincoln, S.Y. (2008). Collecting and interpreting qualitative materials. Sage.

Doty, G. W. (2000). Mythography: The study of myths and rituals (2. Ed.). The University of Alabama Press.

Drobnick, J. (2002). Toposmia: Art, Scent, and interrogations of spatiality. Angelaki: Fournal of Theoretical Humanities, 7(1), 31-47.

Duncan, C. (1995). Civilizing rituals: Inside public art museums. Routledge.

Evola, V., \& Skubisz, J. (2019). Coordinated collaboration and nonverbal social interactions: A formal and functional analysis of gaze, gestures, and other body movements in a contemporary dance improvisation performance. Fournal of Nonverbal Behavior, 43(4), 451-479. 
Francis, P. Jr. (1984). Plants as human adornment in India. Economic Botany, 38(2), 194-209.

Franko, M. (2006). Dance and the political: States of exception. Dance Research fournal, 38(1/2), 3-18.

Fowler-Smith, L. (2018). Adorning and adoring: The sacred trees of India. Fournal for the Study of Religion, Nature and Culture, 12(3), 261-284.

Grande, S. (2008). Red pedagogy: The un-methodology. In N. K. Denzin, Y. S. Lincoln, \& L. T. Smith (Eds.), Handbook of Critical and Indigenous methodologies (pp. 233-251). Sage Publications.

Green, J., \& Stinson, W. S. (1999). Postpositivist research in dance. In S. H. Fraleigh \& P. Hanstein (Eds.), Researching dance: Evolving modes of inquiry (pp. 91-123). University of Pittsburgh Press.

Gorman-Murray, A. (2008). Reconciling self: Gay men and lesbians using domestic materiality for identity management. Social and Cultural Geography, 9(3), 283-301.

Gupta, V. S., Russell, A., \& Lo, E. (2007). Meditation. Fournal of Religion E Spirituality in Social Work: Social Thought, 26(2), 49-61.

Haseman, B. (2006). A manifesto for performative research. Media International Australia incorporating Culture and Policy, 118(1), 98-106.

Highwater, J. (1978). Dance: Rituals of experience. Oxford University Press.

Hiroti, P., \& Martin, R. (2021). Kroppslig læring som forbindelse til sted [Bodily learning through connection to place]. In T. P. Østern, Ø. Bjerke, G. Engelsrud, \& A. G. Sørum (Eds.), Kroppslig laring: Perspektiver og praksiser [Bodily learning: perspectives and practices] (pp.129-140). Cappelen Damm.

Hoskins, R. (2008). 'Our faces in our places': Cultural landscapes Māori and the urban environment. Ministry of Health. https://www.moh.govt.nz/notebook/nbbooks.nsf/0/CB01058B823ACCA6CC2579110071CE1C /\$file/rethinking-urban-environments.pdf\#page=31

Hutchings, A. (2010). Ritual cleansing, incense and the tree of life-observations on some Indigenous plant usage in traditional Zulu and Xhosa purification burial rites. Alternation, 14(2), 189-217.

Insoll, T. (2004). Archaeology, ritual, religion. Routledge.

Jacobs, K., \& Malpas, J. (2013). Material objects, identity and the home: Towards a relational housing research agenda. Theory and Society, 30(3), 281-292.

Kabat-Zinn, J. (2003). Mindfulness-based interventions in context: Past, present, and future. Clinical Psychology: Science and Practice, 10, 144-156.

Kapur, J. (2019). Engaging with sense of smell through textile interaction. Springer Switzerland.

Lakes, R. (2005). The messages behind the methods: The authoritarian pedagogical legacy in Western concert dance technique training and rehearsals. Arts Education Policy Review, 106(5), 3-20.

Liu, C. (2018). Reciting, chanting, and singing: The codification of vocal music in Buddhist canon law. Indian Philosophy, 46, 713-752.

Manning, K. (2000). Rituals, ceremonies, and cultural meaning in higher education. Bergin \& Garvey.

Mar, B. T. (2016). Decolonisation and the Pacific: Indigenous globalisation and the ends of empire. Cambridge University Press.

Marinetti, C. (2018). Theatre as a 'translation zone': Multilingualism, identity and the performing body in the work of Teatro delle Albe. The Translator, 24(2), 128-146.

Mazumdar, S., \& Mazumdar, S. (2009). Religion, immigration, and home making in diaspora: Hindu space in Southern California. Fournal of Environmental Psychology, 29(2), 256-266.

Mckenna, J. D., \& Hughes, K. (2007). The incense bible: Plant scents that transcend world culture, medicine, and spirituality. Routledge.

Mcniff, J. (2013). Action research principles and practice. Routledge.

Meduri, A. (1992). Western feminist theory, Asian Indian performance, and a notion of agency. A fournal of Feminist Theory, 5(2), 90-103.

Mehta, A. (2020). Shakti Puja: Toward a decolonial ritual movement methodology [Unpublished honour's dissertation]. University of Auckland.

Morton, T. (2010). The ecological thought. Harvard University Press.

Negrin, L. (2006). Ornament and the feminine. Feminist Theory, 7(2), 219-235.

North, D. (1990). Institutions, institutional change, and economic performance. Cambridge University Press.

Oldfield, J., \& Forrester, V. (2018). The dancing trope of cross-cultural language education policy. Learning Communities, 23, 64-75.

Park, C. P., \& Pyszczynski, T. (2017). Reducing defensive responses to thoughts of death: Meditation, mindfulness, and Buddhism. Fournal of Personality and Social Psychology, 116(1), 101-118.

Parker, B. S. (2015). Dancing amidst flames: Discomfort and surrender as a catalyst for artistic growth in choreography and performance. [Master's Thesis]. The University of Utah. 


\section{A. Mehta \& S. Foster-Sproull}

Pennacchio, M., Jefferson, V. L., \& Havens, K. (2010). Uses $\mathcal{E}$ abuses of plant-derived smoke: Its ethnobotany as hallucinogen, perfume, incense, and medicine. Oxford University Press.

Phillippi, J., \& Lauderdale, J. (2018). A guide to field notes for qualitative research: Context and conversation. Qualitative Health Research, 28(3), 381-388.

Pinxit, V. (2019). Navigating the methodology of an interdisciplinary art and design practice with conscious bridging. The International fournal of Art $\mathcal{E}$ Design, 38(2), 416-429. https://doi.org/10.1111/jade.12199

Plumwood, V. (2002). Decolonisation relationships with nature. PAN: Philosophy Activism Nature, 2, 7-30.

Protopapa, E. (2011). Performance-making as interruption in practice-led research. Choreographic Practices, 2(1), 103-117.

Raina, D. (2012). Decolonisation and the entangled histories of science and philosophy in India. Polish Sociological Review, 178(2), 187-201.

Ramirez, O. F., \& Christensen, T. (2013). The formalization of the university: Rules, roots, and routes. Higher Education, 65(6), 695-708.

Reid, B. (2007). Creating counterspaces: Identity and the home in Ireland and Northern Ireland. Environment and Planning D: Society and Space, 25, 933-950.

Roche, J. (2015). Multiplicity, embodiment and the contemporary dancer: Moving identities. Springer.

Roth, D. L. S. C. W. (2006). Adornment as a method of interior design. Studies in Gender and Sexuality, 7(2), 179-194.

Rose, G. (2004). 'Everyone's cuddled up and it just looks really nice': An emotional geography of some mums and their family photos. Social $\mathcal{E}$ Cultural Geography, 5(4), 549-564.

Rountree, K. (2004). Embracing the witch and the goddess: Feminist ritual-makers in New Zealand. Routledge.

Ryan, B. A. (2006). Post-positivist approaches to research. In Researching and writing your thesis: A guide for postgraduate students (pp. 12-26). MACE.

Said, E. (1978). Orientalism. Routledge.

Salazar, C. M. (2013). A humanizing pedagogy: Reinventing the principles and practice of education as a journey toward liberation. Review of Research in Education, 37(1), 121-148.

Scarlett, H. M. (2018). "Why did I get a C?": Communicating student performance using standards-based grading. InSight: A fournal of Scholarly Teaching, 13, 59-75.

Schwartz, P. (2000). Action research: Dance improvisation as dance technique. Fournal of Physical Education, Recreation and Dance, 71(5), 42-46.

Slobin, M. (1994). Music in diaspora: The view from America. Diaspora 3, 243-52.

Smith, S.J. (1994). Soundscape. Area, 26(3), 232-240.

Srinivasan, P. (2019). Decolonising moves: Gestures of reciprocity as feminist intercultural performance. South Asian Diaspora, 11(2), 209-222.

Stoeber, J. (2012). Perfectionism and performance. In M. S. Murphy (Ed.), The Oxford handbook of sport and performance psychology. Oxford University Press.

Sun, Q. (2019). Eastern thoughts, Western practices: Meditation and mindfulness relaxation activities for learning and well-being in adult and higher education. New Directions for Adult and Continuing Education, $161,45-55$.

Teng, J. (2013). Have you ever been with an Asian woman? https://www.metromag.co.nz/arts/arts-art-city/haveyou-ever-been-with-an-asian-woman

Wasasala, J. (2020). Fahra Wasasala. https://jahra.xyz/i-am-we-are

Wiebe, H. P. (2015). Intuitive knowing as spiritual experience. Palgrave Macmillan.

Weiss, R. S. (1995). Learning from strangers: The art and method of qualitative interview studies. Simon \& Schuster.

Williamson, A. (2009). Formative support and connection: Somatic movement dance education in community and client practice. Fournal of Dance and Somatic Practices, 1(1), 29-45.

Young, P. (2017). Feminine divine: A review of orchids. https://pantograph-punch.com/posts/review-orchids 